\title{
Strength Design of Compressed Reinforced Concrete Elements by Deformation Method Based on Extreme Criterion
}

\author{
Oleksandr Shkurupiy ${ }^{1 *}$, Dmytro Lazariev ${ }^{2}$, Yurii Davydenko ${ }^{3}$ \\ ${ }^{1}$ Poltava National Technical Yuri Kondratyuk University, Ukraine \\ ${ }^{2}$ Poltava National Technical Yuri Kondratyuk University, Ukraine \\ ${ }^{3}$ Poltava National Technical Yuri Kondratyuk University, Ukraine \\ *Corresponding AuthorE-Mail:Shbm@Ukr.Net
}

\begin{abstract}
Investigations of the normal sections strength of compressed elements using a deformation method were performed. The shape of the section, the class of concrete and the percentage of reinforcement were taken into account when performing analytical calculations. Analytical, numerical, optimization techniques etc. were used for solving of this task. The results of the analytical calculations and the data of the experimental studies were compared.
\end{abstract}

Keywords: bearing capacity; deformation model; strength; the extreme criterion; ultimate strain.

\section{Introduction}

The tasks [1-3] pays particular attention to the upgrading of such methods $[10,11]$ for a more complete description of mathematical models with allowance for strength characteristics materials, cross-section shapes, etc. This technique takes into account the complete diagrams of the work of reinforcement and concrete. It is realized as an optimization problem. The deformation technique proposed by the authors makes it possible to calculate the characteristics of materials of the normal section in the ultimate state.

The maximum $2\left(\varepsilon_{c l} ; f_{c k, p r i s m}\right)$ of the function (Fig. 1, c) of the diagram of the normal section compressed zone entails a maximum $4\left(\varepsilon_{c u l} ; N_{\max }\right)$ of the function (Fig. 1, d) (axial forcedeformation of the most compressed concrete fiber), that is, to the existence of an extreme criterion [1-3].

$$
N=\left.f\left(\varepsilon_{c m}\right)\right|_{\varepsilon_{c m}=\varepsilon_{c u} l}=\max
$$

Experimental researches by other authors confirm this [2, 4-9]. The deformation technique proposed by the authors, unlike the existing ones, which allows us to analytically determine the ultimate parameters of concrete and reinforcement. In existing methods deforation $\varepsilon_{c u l}$, is determined experimentally. Their values are given in the tabular form of documents [11] depending on the strength class of the compresed concrete. This does not allow taking into account the section shape, the reinforcement percentage and other factors.
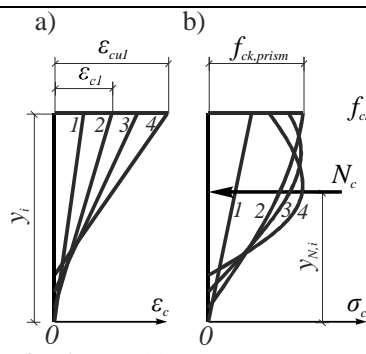
c) d)

Fig. 1: Preultimate $(1,2,3)$ and ultimate (4) development of deformations (a) and tensions (b) in the compressed area of concrete of RCE. Correspondence of states 1, 2, 3, 4 in the diagram of compressing concrete (c) and the curve «the efforts in the section is the deformation in compressed verge of concrete» Dotted lines I, II, III characterize pseudoplastic, plastic, and plastic bodies which are consolidated accordingly

\section{Main Body}

The researches were limited by the task of calculating the strength of a normal section. The functions of stresses and deformations and other characteristics of compressed reinforced concrete element sections were determined according to expressions (2) - (16). The design scheme is shown in Fig. 2.

1 Physical equations for concrete (a) and reinforcement (b):

a) we apply the estimation approved by EN-2 [11]

$\sigma_{c}=f_{c k, p r i s m}\left(K \eta-\eta^{2}\right) /[1+(K-2) \eta]$

in which is the strain degree $\eta$ and is the parameter of the strain-strength (mechanical) property of concrete $K$ determined by the formulas

$\eta=\varepsilon_{c} / \varepsilon_{c 1}, \quad K=1,1 E_{c m} \varepsilon_{c 1} / f_{c k, p r i s m}$,

where $E_{c m}$-is the initial concrete elasticity module, is found by 
the formula $E_{c m}=1,1 \cdot 10^{4} f_{c k, p r i s m}^{0,3}[15] ; f_{c k, p r i s m}, \varepsilon_{c 1}-$ are the stress and strain in the point of curve maximum $\sigma_{c}-\varepsilon_{c}$ (Fig. 1,c). The strain $\varepsilon_{c l}$ is determined by ECB-FIP as

$$
\varepsilon_{c 1}=70 \cdot 10^{-5} f_{c k, p r i s m}^{0,31}
$$
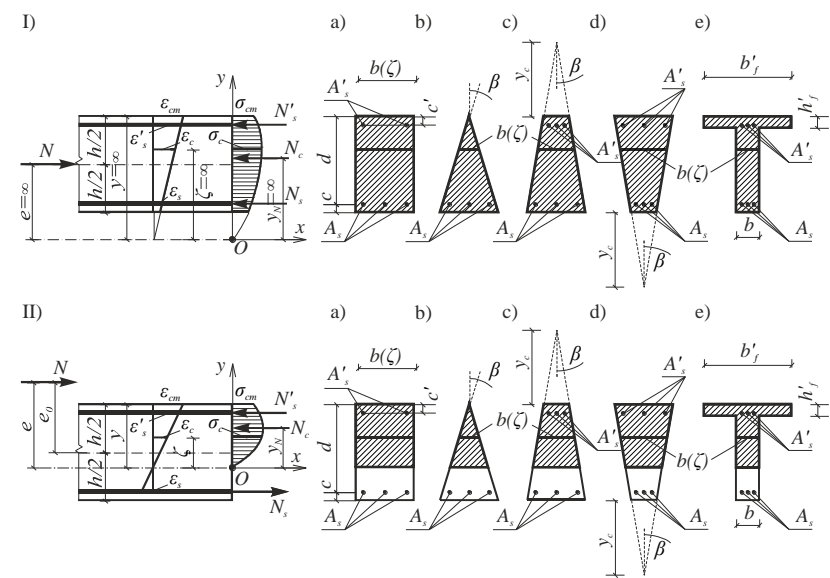

Fig. 2: The design schemes of normal cross sections compressed element

b) The dependences between stresses and strains in the reinforcement with physical $\sigma_{y}$ (Fig.3a) and conventional $\sigma_{0,2}$

(Fig.3, b) yield strength were determined according to equations (5) - (8).
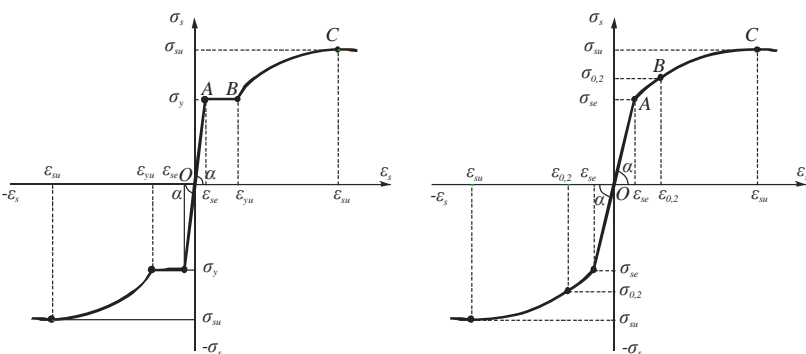

Fig. 3: Complete diagrams of the reinforcement work

$\sigma_{s}=\sigma_{s u} /\left(1-\varepsilon_{y u} / \varepsilon_{s u}\right)^{2}-\left[\left(1-\sigma_{y} / \sigma_{s u}\right)\left(2-\varepsilon_{s} / \varepsilon_{s u}\right) \times\right.$
$\left.\times \varepsilon_{s} / \varepsilon_{s u}++\sigma_{y} / \sigma_{s u}+\left(\varepsilon_{y u} / \varepsilon_{s u}\right)^{2}-2 \varepsilon_{y u} / \varepsilon_{s u}\right]$

where $\varepsilon_{y u}-$ is the deformation of reinforcement (point $B$, fig. 3,a), $\sigma_{s u}, \varepsilon_{s u}$ - is the strength limit (stress) and strain in the maximum point of diagram $C \sigma_{s}-\varepsilon_{s}$ (fig. 3,a).

The diagram shown in figure $3, \mathrm{~b}$ is described by the expressions (6) - (8).

$\left\{\begin{array}{l}0 \leq \varepsilon_{s} \leq \varepsilon_{s e}, \quad \sigma_{s}=E_{s} \varepsilon_{s}, \\ \varepsilon_{s e} \leq \varepsilon_{s} \leq \varepsilon_{0,2}, \sigma_{s}=-\alpha \varepsilon_{s}^{2}+\beta \varepsilon_{s}+\gamma, \\ \varepsilon_{0,2} \leq \varepsilon_{s} \leq \varepsilon_{s u}, \sigma_{s}=-a \varepsilon_{s}^{2}+b \varepsilon_{s}+c,\end{array}\right.$

where

$\left\{\begin{array}{l}\alpha=p-q, \quad \beta=2 p \varepsilon_{0,2}-q\left(\varepsilon_{s e}+\varepsilon_{0,2}\right), \\ \gamma=\sigma_{0,2}-p \varepsilon_{0,2}^{2}+q \varepsilon_{s e} \varepsilon_{0,2}, \\ p=\left(\sigma_{0,2}-\sigma_{s e}\right) /\left(\varepsilon_{0,2}-\varepsilon_{s e}\right)^{2}, \quad q=\sigma_{0,2}^{\prime} /\left(\varepsilon_{0,2}-\varepsilon_{s e}\right), \\ \sigma_{0,2}^{\prime}=-2 a \varepsilon_{0,2}+b,\end{array}\right.$

$a=\left(\sigma_{s u}-\sigma_{0,2}\right) /\left(\varepsilon_{s u}-\varepsilon_{0,2}\right)^{2}, b=2 a \varepsilon_{s u}, c=\sigma_{s u}-a \varepsilon_{s u}^{2}$, where the following parameters are used: the modulus of elasticity $E_{s}$, proportionality limit $\sigma_{s e}$, conventional yield point $\sigma_{0,2}$, strength limit $\sigma_{s u}$ and the strains corresponding to these limits $-\varepsilon_{s e}, \varepsilon_{0,2}, \varepsilon_{s u}$ [2].

2 Geometrical equations are based on the hypothesis of plane sections and this allows to express through the $\varepsilon_{c m}$ (Fig. 2)

$$
\begin{aligned}
& \varepsilon_{c}=\varepsilon_{c m} \cdot \zeta / y ; \\
& \varepsilon_{s}=\varepsilon_{c m} \cdot(d / y-1) ; \\
& \varepsilon_{s}^{\prime}=\varepsilon_{c m} \cdot\left(1-c^{\prime} / y\right),
\end{aligned}
$$

where $y, c^{\prime}, d$-geometric parameters shown in fig. 2 .

Provided that the relative deformation of the most compressed concrete fibre in the normal section is described by the expression $\alpha=\varepsilon_{c m} / \varepsilon_{c l}$, then the value $\eta$ will be equal $\eta=\alpha \zeta / y$.

3 Equations of statics

$$
\sum X=0 ; \quad N-\sigma_{s} \cdot A_{s}-N_{c}-\sigma_{s}^{\prime} \cdot A_{s}^{\prime}=0 ;
$$

$$
\begin{aligned}
\sum M_{O}=0 ; \quad & N \cdot e-N_{c} \cdot y_{N}-\sigma_{s}^{\prime} \cdot A_{s}^{\prime} \cdot\left(y-c^{\prime}\right)- \\
& -\sigma_{s} \cdot A_{s} \cdot(d-y)=0
\end{aligned},
$$

where $N_{c}-$ is the concrete resultant of the compressed part

$N_{c}=\int_{0}^{y} \sigma_{c} b(\zeta) d \zeta=N_{c}(\alpha, y)$

$e-$ is the eccentricity application of the axial force $N$ (Fig. 2)

$e=e_{0}-h / 2+y=e(y)$

$e_{0}-$ is the eccentricity of the force $N$ application relatively to the center of the normal cross section, $e_{0}=0$;

$y_{N}-$ shown in fig. 2 and is calculated by the formula

$y_{N}=\left(\int_{0}^{y} \sigma_{c} \zeta \cdot b(\zeta) d \zeta\right) / N_{c}=y_{N}(\alpha, y)$.

To determine the unknown parameters $N, \alpha, y$, we use expressions (2) - (16). As a result, we obtain a system of equations $(17,18)$

$\left\{\begin{array}{l}N-\sigma_{s}(\alpha, y) \cdot A_{s}-N_{c}(\alpha, y)-\sigma_{s}^{\prime}(\alpha, y) \cdot A_{s}^{\prime}=0 ; \\ N \cdot e(y)-N_{c}(\alpha, y) \cdot y_{N}(\alpha, y)-\sigma_{s}^{\prime}(\alpha, y) \cdot A_{s}^{\prime}\left(y-c^{\prime}\right)- \\ -\sigma_{s}(\alpha, y) \cdot A_{s}(d-y)=0 .\end{array}\right.$

To notice the unspecified $N, \alpha, y$ the equations (17), (18) and the extra state in the normal cross section shape of extreme strength criterion (1). The solution of equations (17), (18) with the goal function (1) taken into account is realized as an optimization problem of nonlinear mathematical programming [13]. The algorithm of this methodology for calculating such elements is implemented in the program CRC-12 for PC (Fig. 4). 


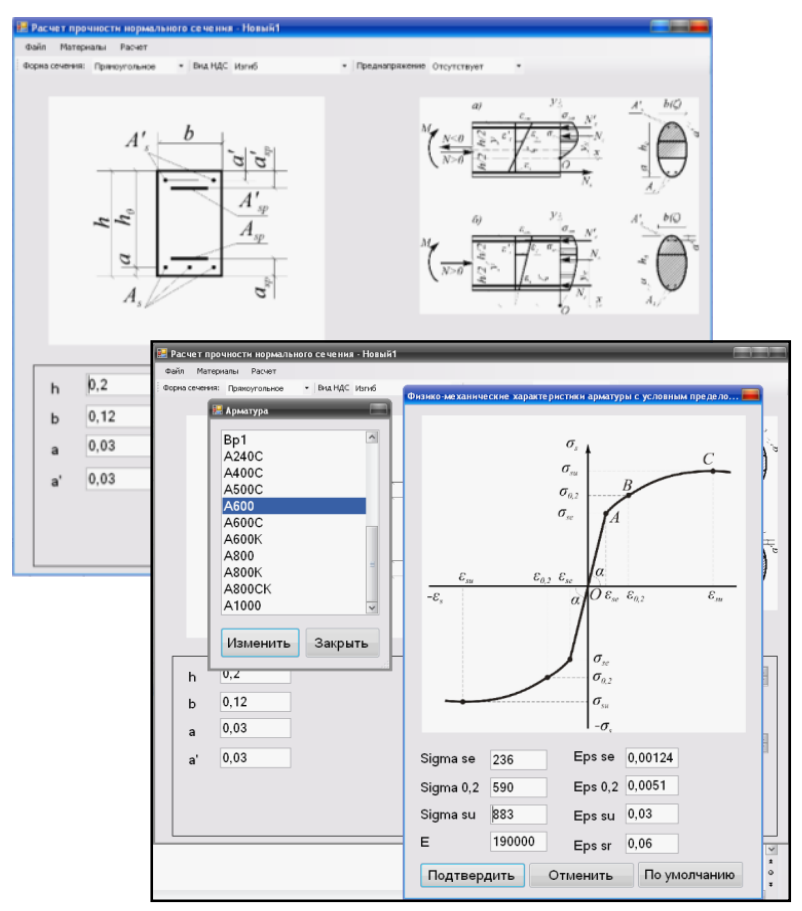

Fig. 4: Software program CRC - 12

The results of calculations of such elements on the basis of the above method were compared with the data of the experimental researches. Statistical processing of the results comparison was carried out. The initial parameters of the reinforcement were taken from the experimental data [14] (Fig. 3).

The initial data for research were taken: different shapes normal

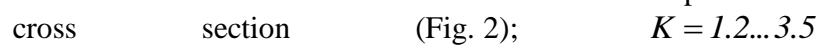
$\left(f_{c d}=120 M P a \ldots 7.5 \mathrm{MPa}\right) ;$ the reinforcement percentage $\rho_{f}=0.41 \ldots 5.03 \%$; the reinforcement class - $A 400 C$; $b=0,25 m, h=0,3 m, \operatorname{tg} \beta=0.217$ (Fig. 2, a-d); $h=0,3 m$, $b=0,12 m, \quad h_{f}^{\prime}=0,06 m, \quad b_{f}^{\prime}=0,25 m \quad$ (Fig. 2, e). The calculations result of the normal section ultimate strength parameters according to the above technique are shown in Figures 5-9.

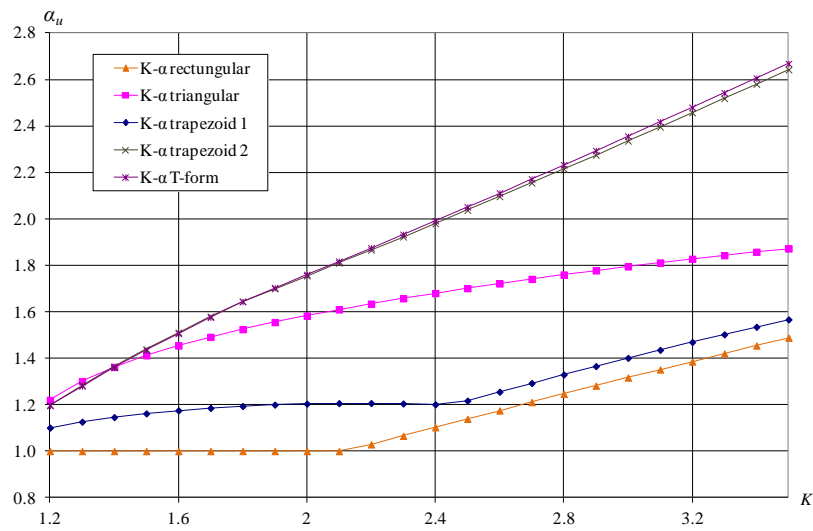

Fig. 5: Dependence of ultimate relative strain $\alpha_{u}=\varepsilon_{c u l} / \varepsilon_{c l}$ of the compressed concrete part from normal cross section shape and $K$ under central compression with symmetric reinforcement (2Ø16 A400C in the compressed and tensile parts of section)

As can be seen from Fig. 5, the parameter $K$ essentially depends on the $\varepsilon_{c u}$, on cross section shape and on percentage of reinforcement $\rho_{f}$ [3]. The ultimate deformation $\varepsilon_{c u}$ significantly changes its values when the stresses in the reinforcement exceed the $\sigma_{y}$ (Figure 6). a)

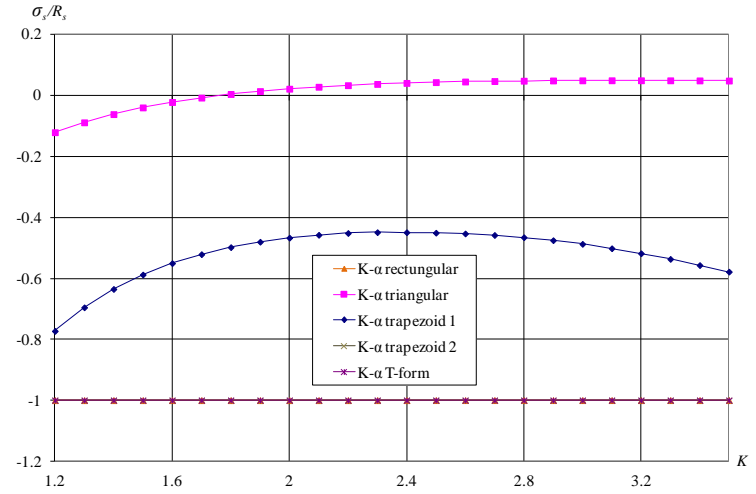

b)

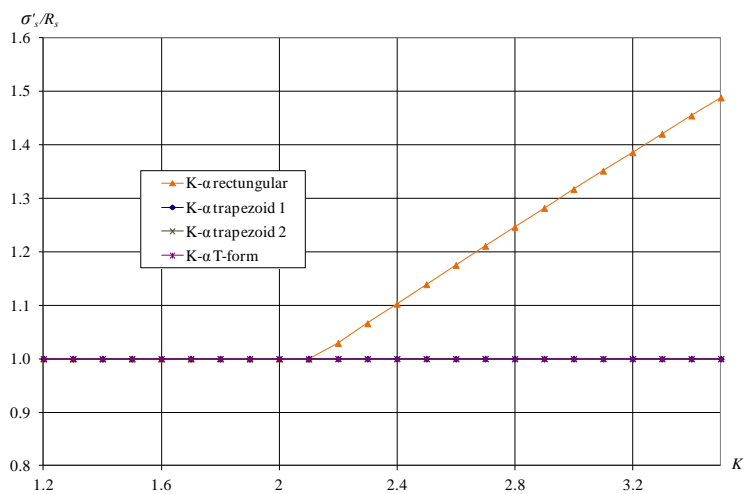

Fig. 6: The influence of parameter $K$ and normal cross section shape of the centrally compressed element on relative stresses in reinforcement of compressed and tension parts

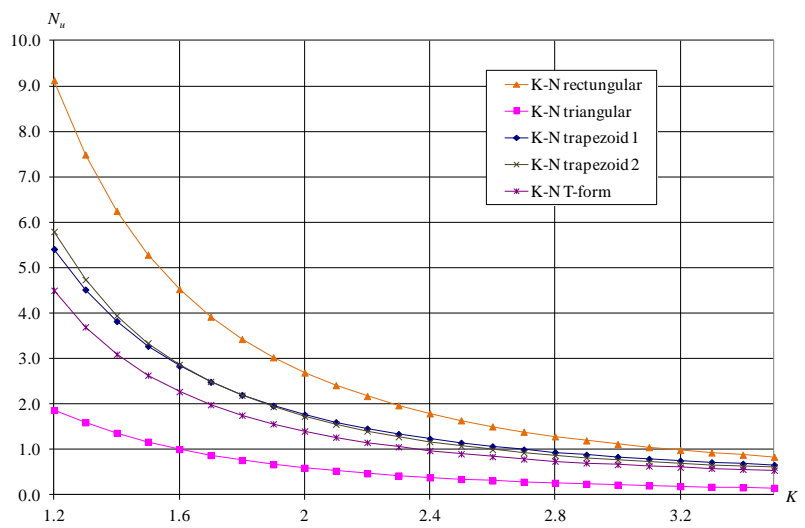

Fig. 7: Dependence of the normal section strength of the centrally compressed element $\left(N_{u}\right)$ on the parameter $K$ for symmetric reinforcement $(2 \varnothing 16 \mathrm{~A} 400 \mathrm{C}$ in the compressed and tensile parts of section)

The dependence of $N_{u}$ on the normal section shapes and the parameter $K$ for symmetric reinforcement is shown in Fig. 7. The analysis of the graphs shows that $N_{u}$ essentially depends on the section shape. 


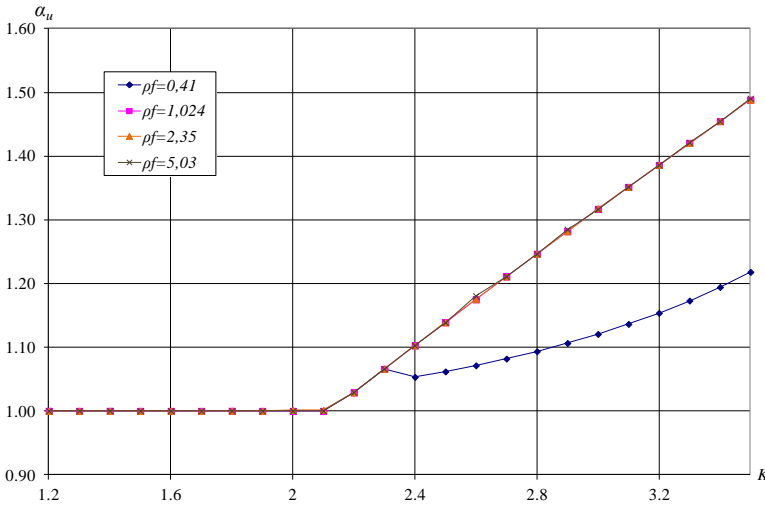

Fig. 8: Dependence of ultimate strain $\alpha_{u}$ of reinforcement percentage $\rho_{f}$, of parameter $K$ of centrally compressed element

Analysis of the data on the graphs (Fig. 8) shows the dependence of the $\alpha_{u}-K$ parameters on different reinforcement percentages in the $\rho_{f}=0,41 \ldots 5,03 \%$. As a consequence of this graph, it should be noted that when the class of concrete and the reinforcement percentage change, the ultimate characteristics of the section parameters and its strength change significantly.

Figure 9 shows the dependence curves of the strain $\varepsilon_{c u}$ from concrete strength class $f_{c k, p r i s m}$, obtained according to DM of ESC for different stress-strain states RCE and with different number of reinforcement in stretched and compressed zones of normal cross section (curves 1-6) and curves 7 and 8 which correspond to the recommendations of Eurocode 2 [11] and SRIBC [18]. Calculations according to DM with ESC are executed for RCE rectangular reinforcement of class A400C without preliminary tension.

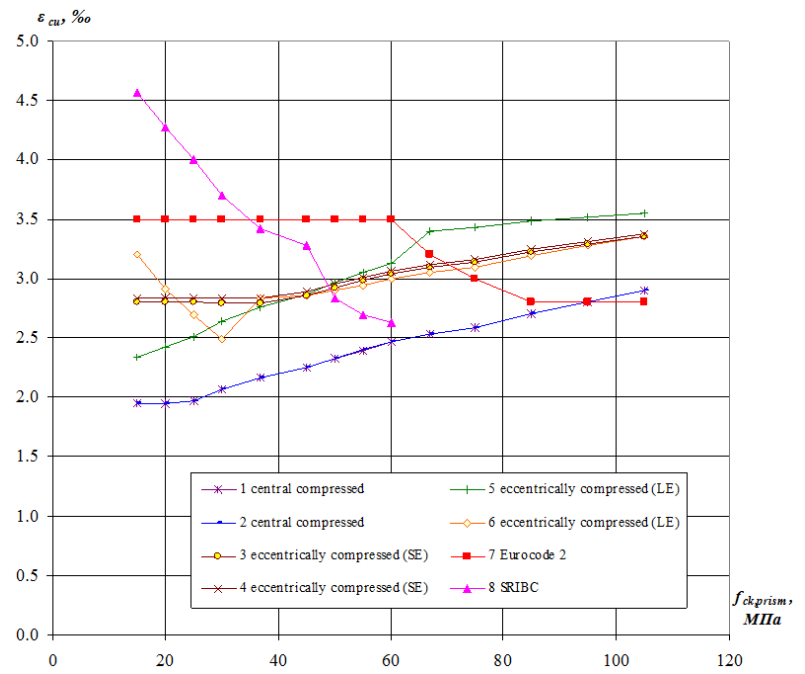

Fig. 9 Curves $f_{c k, p r i s m}-\varepsilon_{c u}$ according to DM with ESC for $\rho_{f}=\rho_{f}^{\prime}($ in $\%): 1,3,5-0,88 ; 2,4,6-2,7$

Curves $f_{c k, p r i s m}-\varepsilon_{c u}$ according DM with ESC (fig. 9) form a beam that narrows from $\varepsilon_{c u} \approx 2 \ldots 4 \%$ for the low strength to $\varepsilon_{c u} \approx 2,9 \ldots 3,7 \%$ for the high concrete strength. It makes for the logical relative position of curves. In the middle of the beam there are curves with increased $\rho_{f}$, during the eccentrically compression of small (SE) and large (LE) eccentricities. Lower curves for the central compressed RCE almost repeated strain curves of concrete under axial compression $\varepsilon_{c l}$ and therefore do not cause doubts in their reality. The upper curves are approximately at the constant level to $\varepsilon_{c u} \approx 3,7 \%$ close to the adopted in Eurocode 2 constant value $\varepsilon_{c u}=3,5 \%$ for concretes of low and medium strength. But according to DM with ESC the level of $\varepsilon_{c u} \approx 3,7 \%$ is retained for high strength concrete up to $B=105 \mathrm{MPa}$, for which in Eurocode 2 $\varepsilon_{c u} \approx 2,8 \%$. However, in tests of beams with cylindrical strength of concrete $f_{c m}=97,9 \ldots 108,3 \mathrm{MPa}$, reinforcement of physical yield point $\sigma_{s y}=430,9 \mathrm{MPa}$ and parameter $\xi=y / h=0,282$ the value $\varepsilon_{c u}=3,21 \ldots 3,74 \%$ was obtained [19], that means that the experimental data support the calculation $\varepsilon_{c u}$ according to DM with ESC better than

Eurocode 2.

Reduction of the ultimate strain for the high-strength concrete in Eurocode 2 is caused by the increased fragility and taken in order to ensure reliability of RCE.

Figure 9 shows that the curve $f_{c k, p r i s m}-\varepsilon_{c u}$ of Eurocode 2 is located in the «corridor» limited with curves DM with ESC though for high-strength concrete curves it gradually decreases to the curves under central compression $f_{c k, p r i s m}-\varepsilon_{c u}$. SRIBC curve; which has a big slope and crosses the indicated corridor in the area of low and medium strength concrete, behaves absolutely differently.

The technique given above was applied for normal cross section of centrally compressed RCE strength calculation. The experimental data of different authors [16, 17] were also used. The design results have being compared with the experimental data of the normal cross section strength of the reinforced concrete elements. The results of the strength calculation of compressed elements according to the above technique were compared with the experimental data (33 samples). Statistical analysis of the sampling of the correlation ratios shows their good convergence. The arithmetic mean deviation is 0,978 . The mean square deviation is 0,083 . The variation coefficient is $8,5 \%$.

\section{Conclusion}

1. The implementation of the algorithm of this technique for calculating the strength of a normal section is released by the authors in the software package for PC and allows to analyze the full complex of parameters in the limiting stage, to analyze the actual work of the concrete and reinforcement.

2. The proposed method for calculating the strength of compressed concrete elements of normal cross section makes it possible to take into account influence of strength concrete, the reinforcement amount, the section shapes, etc. on the $\varepsilon_{c u l}$. It is evident from experiments $[16,17]$.

3. Accounting the real diagrams of reinforcement renders the essential effect on the characteristics of the normal cross section and on its strength in ultimate state. Over-reinforcing of the normal cross section reinforced concrete element significantly increases the ultimate strain of most compressed fibre of the concrete. Decreasing of concrete strength having constant reinforcement results in the same phenomenon.

4. Ultimate strain $\varepsilon_{c u}$ depends not only on the parameters $E_{c m}$, $f_{c k, p r i s m}$ of concrete, but also on the character of RCE concrete complete compression diagram the number of reinforcement $A_{S}, A_{S}^{\prime}$, and its location, section shape, the character of the complete diagram of reinforced steel and other factors that are taken into account only in DM with ESC. Therefore $\varepsilon_{c u}$, is not a criterion value, which determines the state of destruction only of concrete, and is one of the parameters of the ultimate state of 
the normal cross section RCE and it cannot be constant, as it is accepted in Eurocode-2 [11] and DBN V.2.6-98: 2009 [18]

\section{References}

[1] Mitrofanov V., Shkurupij A., Mitrofanov B., Lazarev D., O vliyanii formy normal'nogo secheniya na predel'nuyu deformaciyu betona szhatoj zony, Zbirnyk naukovykh prats (haluzeve mashynobuduvannia, budivnytstvo), Poltava: PoltNTU, Vol. 15, (2005), pp. 89-94.

[2] Mitrofanov V., Prakticheskoe primenenie deformacionnoj modeli s ehkstremal'nym kriteriem prochnosti zhelezobetonnyh ehlementov, Kommunal'noe hozyajstvo gorodov. Seriya: Arhitektura i tekhnicheskie nauki, Kyiv: Tekhnika, Vol. 60 , (2004), pp. 29-48.

[3] Mytrofanov V., Shkurupii A., Lazariev D., Mytrofanov B., Vplyv mitsnosti betonu ta kilkosti armatury na hranychni kharakterystyky normalnoho pererizu zalizobetonnykh elementiv, Resursoekonomni materialy, konstruktsii, budivli ta sporudy: Zbirnyk naukovykh prats, Rivne: NUVHP, Vol. 12, (2005), pp. 208-217.

[4] Noghabai K., Beams of fibrous concrete in shear and bending: Experiment and model. ASCE J. Struct. Eng., Vol. 126, (2000), pp. 243-251, doi: 10.1061/(ASCE)0733-9445(2000)126:2(243).

[5] Hwang J.-H., Lee D.H., Ju H., Kim K.S., Seo S.-Y., Kang J.-W., Shear behavior models of steel fiber reinforced concrete beams modifying softened truss model approaches. Materials, Vol. 6, (2013), pp. 4847-4867. doi: 10.3390/ma6104847.

[6] Ezeldin A.S., Balaguru P.N., Normal and high strength fiber reinforced concrete under compression. ASCE J. Mater. Civil Eng., Vol. 4, (1992), pp. 415-429. doi: 10.1061/(ASCE)08991561(1992)4:4(415).

[7] Mansur M.A., Chin M.S., Wee T.H., Stress-strain relationship of high-strength fiber concrete in compression. ASCE J. Mater. Civil Eng., Vol. 11, (1999), pp. 21-29. doi: 10.1061/(ASCE)0899-1561(1999)11:1(21).

[8] Nataraja M., Dhang N., Gupta A., Stress-strain curves for steelfiber reinforced concrete under compression. Cement Concr. Compos., Vol. 21, (1999), pp. 383-390. doi: 10.1016/S09589465(99)00021-9.

[9] Bencardino F., Rizzuti L., Spadea G., Swamy R.N., Stress-strain behavior of steel fiber-reinforced concrete in compression. J. Mater. Civil Eng., Vol. 20, (2008), pp. 255-263. doi: 10.1061/(ASCE)0899-1561(2008)20:3(255).

[10] Practical design of reinforced and prestressed concrete structures based on the CEB - FIP mode code (MC 78), London: Thomas Telford Limited, (1984), $36 \mathrm{p}$.

[11] CEB - FIP Eurocode 2: Design of Concrete Structures. Part 1: General Rules and Rules for Buildings, ENV $1992-1-1$, Brussels: CEN, (1991), 253 p.

[12] Holand I., Strength Concrete in Model Code 90. 5th Int. Symp. on Utilization of HS/HP Concrete, 20-24 June 1999, Sandefjord, Norway. Procedures, Vol. 1, (1999), pp. 362-367.

[13] Minu M., Matematicheskoe programmirovanie: teoriya i algoritmy, Perevod s francuzskogo, Moskva: Nauka, (1990), $488 \mathrm{~s}$.

[14] Karpenko N., Muhamediev T., Ishodnyie i transformirovannyie diagrammyi deformirovaniya betona i armaturyi, Napryazhennodeformirovannoe sostoyanie betonnyih i zhelezobetonnyih konstruktsiy: Sbornik nauchnyih trudov, Moskva: NIIZhB Gosstroya SSSR, (1986), pp. 7-25.

[15] Shkurupii O., Babych Ye., Analitychne vyznachennia fizykomekhanichnykh kharakterystyk betonu, Resursoekonomni materialy, konstruktsii, budivli ta sporudy: Zbirnyk naukovykh prats, Rivne: NUVHP, Vol. 21, (2011), pp. 401-407.

[16] Takeuti A., de Hanai J., Strength and Ductility of Reinforced Strength Concrete Columns Strengthened with High-Performance Concrete Jackets. 5-th Int. Symp. on Utilization of HS/HP Concrete 20-24 June 1999, Sandefjord, Norway, Proceedings, Vol. 1, (1999), pp. 646-655.

[17] Kudryavcev A., Dovgalyuk V., Vilkov K., Prochnost' treshchinostojkost' kolonn karkasnyh zdanij serii II-04, Issledovanie konstrukcij iz betonov na poristyh zapolnitelyah: Sbornik nauchnyh trudov NIIZHB Gosstroya SSSR, Moskva: Strojizdat, (1981), pp. 36-51.

[18] DBN V.2.6.-98:2009. Betonni ta zalizobetonni konstruktsii. Osnovni polozhennia, Kyiv: Minrehionbud Ukrainy, 2011: 71 p.
[19] Weiss W. J., Guler K., Shah S. P., An Experimental Investigation to Determine the Influence of Size on the Flexural Behavior of High Strength Reinforced Concrete Beams. 5-th Int. Symp. on Utilization of HS/HP Concrete. 20-24 June 1999, Sandefjord, Norway. Proc., Vol. 2, (1999), pp. 709-718 